\title{
PEMBERDAYAAN TANAH WAKAF YANG DIKELOLA YAYASAN BERDASARKAN NILAI KEADILAN
}

\author{
Sutrisno \\ Advokat Demak \\ lbhkalijogo@gmail.com
}

\begin{abstract}
Wakaf was originally done by oral means intended for worship activities such as mosques, mosques, madrassas or tombs. The existence of such representation has been running since the entry of Islam in the Nusantara. After Indonesia's independence, the rules on the procedure of regulation began to be arranged as proven by the issuance of Government Regulation Number 28 Year 1977 regarding Ownership of Land Ownership. The provisions in this regulation govern the representation of the land as well as procedures and procedures written endowments poured in the Deed of Pledge Wakaf. Then followed by the issuance of Presidential Instruction No. 1 of 1991 on the Compilation of Islamic Law which regulates the wakaf of moving goods or not moving. The research approach used in this research is sociological legal method or socio-legal research approach. The result of research indicates that one of the causes of empowerment of waqf land managed by foundations is not based on the value of justice due to the low level of human resources and professionalism of individual Nadzir in the management of wakaf land at this time get less attention and also special coaching from BWI and Kemenag. So that the number of unproductive, abandoned and even lost wakaf land and one weakness of empowerment of wakaf land managed by the foundation now is Nadzir, Waqf Board of Indonesia and Ministry of Religious Affairs have little active role in carrying out their respective duties as specified in the Laws and Regulations, Invite waqf.
\end{abstract}

Keywords : Land of Endowments, Foundation, Values of Justice

\begin{abstract}
Abstrak
Wakaf pada mulanya dilakukan dengan cara lesan yang diperuntukkan untuk kegiatan peribadatan seperti masjid, musholla, madrasah atau makam. Eksistensi perwakafan seperti itu telah berjalan sejak masuknya agama Islam dibelahan Nusantara. Setelah Indonesia merdeka, aturan tentang prosedur perwakafan mulai ditata terbukti dengan terbitnya PP Nomor 28 Tahun 1977 Tentang Perwakafan Tanah Milik. Ketentuan di dalam PP ini mengatur tentang perwakafan tanah serta prosedur dan tata cara perwakafan tertulis yang dituangkan di dalam Akta Ikrar Wakaf. Kemudian disusul terbitnya Inpres Nomor 1 Tahun 1991 Tentang Kompilasi Hukum Islam yang mengatur tentang wakaf barang bergerak maupun tidak bergerak. Pendekatan penelitian yang digunakan dalam penelitian ini adalah metode pendekatan yuridis sosiologis atau socio-legal research. Hasil penelitian menyebutkan bahwa salah satu penyebab pemberdayaan tanah wakaf yang dikelola yayasan saat ini belum berdasarkan nilai keadilan dikarenakan rendahnya tingkat SDM dan profesionalisme Nadzir perseorangan dalam pengelolaan tanah wakaf pada saat ini kurang mendapatkan perhatian maupun pembinaan khusus dari BWI maupun Kemenag. Sehingga ditemui banyaknya tanah wakaf yang tidak produktif, terlantar dan bahkan hilang serta salah satu Kelemahan pemberdayaan tanah wakaf yang dikelola yayasan saat ini adalah Nadzir, Badan Wakaf Indonesia maupun Kemenag setempat kurang berperan aktif dalam melaksanakan tugasnya masing-masing sebagaimana yang ditentukan dalam Peraturan Perundang-undangan wakaf.
\end{abstract}

Kata kunci : Tanah Wakaf, Yayasan, Nilai Keadilan 


\section{A. PENDAHULUAN}

Bagi masyarakat Indonesia yang mayoritas masyarakatnya pemeluk agama Islam, wakaf merupakan salah satu ibadah yang mempunyai dimensi sosial di dalam agama Islam. Praktik wakaf yang terjadi dalam kehidupan masyarakat belum sepenuhnya berjalan tertib dan efisien, sehingga dalam berbagai kasus harta benda wakaf tidak terpelihara sebagaimana mestinya, terlantar atau beralih ke tangan pihak ketiga dengan cara melawan hukum. Keadaan demikian itu, tidak hanya karena kelalaian atau ketidakmampuan nadzir dalam mengelola dan mengembangkan harta benda wakaf tetapi karena juga sikap masyarakat yang kurang peduli atau belum memahami status harta benda wakaf yang seharusnya dilindungi demi untuk kesejahteraan umum sesuai dengan tujuan, fungsi, dan peruntukan wakaf. ${ }^{1}$

Berbicara tentang hukum perwakafan, menurut Ameer Ali, hukum wakaf merupakan cabang yang terpenting dalam hukum Islam, sebab wakaf terjalin ke dalam seluruh kehidupan ibadat dan perekonomian sosial kaum muslimin. ${ }^{2}$ Para ahli hukum Islam berpendapat bahwa lembaga wakaf di dalam Islam mempunyai potensi sebagai sumber daya sosial dan ekonomi yang besar, dengan upaya dasar untuk meningkatkan kualitas umat Islam dan seluruh aktivitasnya sepanjang yang relevan dengan agama Islam. ${ }^{3}$ Lembaga wakaf juga sangat penting dalam perkembangan agama Islam dan kemajuannya, yang mana dapat memberikan kepastian dan pembuktian hukum apabila terjadi sengketa dikemudian harinya.

Undang-Undang Pokok Agraria Nomor 5 Tahun 1960, Pasal 49 ayat (3) menyatakan bahwa "Perwakafan Tanah Milik dilindungi dan diatur dengan Peraturan Pemerintah" untuk melaksanakan Pasal 49 ayat (3) tersebut, pemerintah mengeluarkan Undang-Undang Nomor 41 Tahun 2004 Tentang Wakaf. Dengan berlakunya Undang-Undang Nomor 41 Tahun

1 Rachmadi Usman, 2009, Hukum Perwakafan Di Indonesia, Sinar Grafika, Jakarta, hlm.121.

2 Asaf A.A Fyzee, 1966, Pokok-Pokok Hukum Islam, terj.Arifin Bey M,A., Cet.2, Tinta Mas, Jakarta, hlm. 75.

3 Abdul Gani Abdullah, 1992, "Editorial Tentang Perwakafan" dalam Mimbar Hukum Nomor 7 Tahun III, Al-Hikmah dan Ditbinbapera, Jakarta, hlm.11.
2004 Tentang Wakaf tidak hanya didasarkan pada Hukum Islam semata, tetapi juga didasarkan pada peraturanperaturan yang dibuat oleh Negara Republik Indonesia. Dengan demikian Undang-Undang Nomor 41 Tahun 2004 Tentang Wakaf telah membawa pembaharuan dalam hukum perwakafan di Indonesia, sehingga diharapkan dapat memenuhi hakekat dan tujuan dari perwakafan itu.

Sebenarnya tanah wakaf yang begitu luas dan menempati beberapa lokasi yang strategis memungkinkan untuk dikelola dan dikembangkan secara produktif. Sebagai contoh, cukup banyak tanah wakaf yang di atasnya dibangun masjid atau musholla, sedang sisa tanahnya yang masih luas bisa dibangun gedung pertemuan untuk disewakan kepada masyarakat umum. Hasil penyewaan gedung tersebut dapat digunakan untk memelihara masjid atau misalnya ada tanah wakaf yang terletak cukup strategis dalam usaha bisa di bangun ruko atau gedung perkantoran yang bisa dikelola sendiri atau disewakan dan hasilnya bisa untuk perawatan gedung wakaf yang telah ada atau untuk menunjang kegiatan atau pemberdayaan ekonomi lemah yang ada di sekitarnya. ${ }^{4}$

Didalam praktik pelaksanaan perwakafan tanah ini sebelum diatur dalam Hukum Agraria Nasional, pelaksanaannya sangat sederhana yaitu cukup ditandai oleh adanya rasa kepercayaan dan terpenuhinya beberapa unsur dan syarat tertentu sesuai dengan ajaran hukum Islam saja. Dengan cukup diikrarkan di hadapan nadzir serta disaksikan oleh beberapa orang saksi, maka telah dianggap selesailah pelaksanaan wakaf tersebut. Sebagai akibatnya, sering tidak ada usaha pengadministrasiannya sama sekali atau hanya sampai pencatatan ke desa saja, tidak sampai pada instansi yang berwenang terhadap masalah pertanahan.

Pelaksanaan perwakafan seperti tersebut di atas, memang lebih mudah karena tidak ada prosedur dan tata cara yang rumit dan berbelitbelit. Akan tetapi sebagai akibatnya hal tersebut tidak menjamin kelestarian dan kesinambungan pengelolaan wakaf dari generasi ke generasi berikutnya secara tertib, yang disebabkan oleh tidak dilindunginya perwakafan tanah tersebut

4 Ibid, Hal. 77 
dengan suatu alat bukti yang kuat atau dengan kata lain belum terdapat adanya kepastian hukum di dalamnya.

Akibat yang sering ditimbulkan dengan tidak diaturnya secara tegas dan tuntas masalah perwakafan tanah tersebut, yaitu memudahkan timbulnya penyimpangan dan penyelewengan dari hakekat dan tujuan wakaf itu sendiri, misalnya dengan banyaknya timbul persengketaanpersengketaan yang terjadi karena adanya perubahan status atau peruntukkan wakaf, seperti perubahan tanah wakaf menjadi milik perseorangan atau berubahnya peruntukkan yaitu yang pada awalnya diperuntukkan untuk masjid tiba-tiba oleh nadzirnya dimanfaatkan untuk keperluan lain tanpa adanya pendekatan dan musyawarah terlebih dahulu dengan pihak yang berkepentingan (dalam hal ini adalah wakif atau keluarga), persengketaan lain yang sering timbul adalah kasus dimana apabila setelah wakif meninggal dunia, sebagian ahli warisnya menolak dan tidak mengakui bahwa tanahnya tersebut adalah tanah wakaf.

Berubahnya status tanah wakaf menjadi tanah milik pribadi merupakan suatu akibat tidak adanya bukti-bukti tertulis atau bukti lain yang menunjukkan tanah-tanah tersebut adalah tanah wakaf. Dalam Instruksi Presiden Nomor 1 Tahun 1991 tentang Kompilasi Hukum Islam juga telah diharuskan adanya perwakafan secara tertulis, tidak cukup dengan lisan saja. Tujuannya adalah untuk memperoleh bukti otentik yang dapat dipergunakan untuk pendaftaran pada Kantor Pertanahan Kabupaten atau Kota dan untuk keperluan menyelesaikan persengketaan yang kemungkinan akan timbul dikemudian hari mengenai tanah yang diwakafkan. Untuk keperluan tersebut seorang yang hendak mewakafkan tanah harus membawa buktibukti kepemilikan tanah (sertifikat) dan membawa surat-surat lain yang menjelaskan tidak adanya halangan untuk mewakafkan tanah tersebut.

Dari fakta yang ada penulis menentukan perumusan masalah yang akan di bahas dalam jurnal ini yaitu

1. Apakah Faktor yang menyebabkan Pemberdayaan tanah wakaf yang dikelola yayasan saat ini belum berdasarkan nilai keadilan?
2. Bagaimana kelemahan-kelemahan Tanah Wakaf yang Dikelola oleh Yayasan saat ini?

\section{B. Metode Penelitian}

Pendekatan penelitian yang digunakan dalam penelitian ini adalah metode pendekatan yuridis sosiologis atau socio-legal research. ${ }^{5}$ Metode pendekatan yuridis sosiologis dikarenakan permasalahan yang diteliti menyangkut hubungan antara faktor yuridis dan faktor sosiologis. Yuridis artinya penelitian yang didasarkan pada teoriteori hukum, khususnya yang berkaitan dengan Pemberdayaan Tanah Wakaf Yang Dikelola Yayasan. Dasar-dasar yang terdapat dalam perundang-undangan tersebut yang digunakan untuk menganalisis masalah. Sosiologis artinya penelitian yang berhubungan langsung dengan masyarakat, dapat dilakukan melalui pengamatan (observasi), wawancara ataupun penyebaran angket. Jadi, dapat disimpulkan bahwa pendekatan secara yuridis sosiologis adalah pendekatan penelitian hukum yang didasarkan pada aturanaturan hukum yang berlaku dan dilakukan dengan pengamatan (observasi), wawancara ataupun penyebaran angket. Dalam penelitian ini, objeknya adalah tinjauan yuridis sosiologis tentang Rekonstruksi Pemberdayaan Tanah Wakaf Yang Dikelola Yayasan.

\section{Pembahasan}

\section{Faktor yang menyebabkan Pemberdayaan tanah wakaf yang dikelola yayasan saat ini belum berdasarkan nilai keadilan}

Kehadiran UU Yayasan atau Badan Hukum Nir Laba sudah barang tentu akan memberi kepastian hukum yang selama ini tidak ada. Bahkan UU Yayasan atau Badan Hukum Nir Laba dapat menjadi dasar untuk menindak apabila terjadi penyimpangan. Hanya saja apabila Undang-undang Yayasan hanya berisi tentang prosedur pendirian belaka atau prosedur-prosedur lainnya, walaupun baik tetapi tidak optimal. Undang-undangYayasan atau Badan Hukum

5 Ronny Hannitijo Soemitro, 1990, Metodologi Penelitian Hukum dan Jurumetri, Ghalia Indonesia, Jakarta, hlm. 14. 
Nir Laba harus berisi pula ketentuan yang dapat memaksa pengurus beserta organ lainnya untuk mengelola yayasan secara profesional dan baik.

Yayasan sebagai salah satu pengelola wakaf bagi masyarakat berfungsi untuk mencapai maksud dan tujuan tertentu, baik di bidang keagamaan, sosial, dan kemanusiaan. Sehubungan dengan hal tersebut, untuk menjamin kepastian dan ketertiban hukum serta mengembalikan fungsi yayasan sebagai pranata hukum dalam rangka mencapai kegiatan, maksud, dan tujuannya, maka yayasan diatur dengan Undang-Undang Nomor 16 Tahun 2001 tentang Yayasan sebagaimana telah diubah dengan Undang-Undang Nomor 28 Tahun 2004 tentang Perubahan atas Undang-Undang Nomor 16 Tahun 2001 tentang Yayasan. Berdasarkan Undang-Undang tersebut, beberapa ketentuan perlu diatur lebih lanjut dengan Peraturan Pemerintah. Dan Peraturan Pemerintah yang dimaksud adalah Peraturan Pemerintah Nomor 2 Tahun 2013 tentang Perubahan atas Peraturan Pemerintah Nomor 63 Tahun 2008 tentang Pelaksanaan UndangUndang tentang Yayasan. Hal tersebut dimaksudkan, agar Peraturan Pemerintah ini dengan mudah dipahami oleh masyarakat khususnya pengguna. Banyak Yayasan di Indonesia menjadi bermasalah pasca lahirnya Undang- Undang Nomor 16 Tahun 2001 tentang Yayasan jo. Undang-Undang Nomor 28 Tahun 2004 tentang Perubahan atas Undang-Undang Nomor 16 Tahun 2001 tentang Yayasan, dan Peraturan Pemerintah Nomor 2 Tahun 2013 tentang Perubahan atas Peraturan Pemerintah Nomor 63 Tahun 2008 tentang Pelaksanaan Undang-Undang tentang Yayasan. Betapa tidak, salah satu klausul Undang- Undang tersebut menyatakan, bahwa suatu Yayasan yang tidak menyesuaikan diri dengan Anggaran Dasarnya dalam peraturan tersebut bisa dilikuidasi/dibubarkan.

Yayasan tidak berhak atas pengelolaan tanah wakaf yang seharusna dikelola oleh nadzir menurut Undang-Undang No 41 tahun 2004 tentang wakaf sudah jelas tertera bahwa yayasan hanya berhak mengelola tanah wakaf ataupun harta benda wakaf berdasarkan perundang-undangan. Tidak dibenarkan yayasan sebagai nadzir yang menguasai tanah wakaf serta harta benda wakaf, karena itu bisa menyebabkan pembubaran terhadap yayasan serta sengketa yang berkelanjutan. Dengan demikian wakaf yang ada di Indonesia sementara ini relatif sulit berkembang sebagaimana mestinya jika tidak ada upaya yang sungguh-sungguh dan total oleh semua pihak yang terkait dalam rangka memperbaiki system dan profesionalisme pengelolaan tanah wakaf serta harta benda agar diakui oleh pihak lain atau yayasan sebagai milik dan/atau pihak yang wajib mengelolanya. Berikut merupakan faktor yang menyebabkan Pemberdayaan tanah wakaf yang dikelola yayasan saat ini belum berdasarkan nilai keadilan:

a. Rendahnya tingkat SDM dan profesionalisme Nadzir perseorangan dalam pengelolaan tanah wakaf pada saat ini kurang mendapatkan perhatian maupun pembinaan khusus dari BWI maupun Kemenag. Sehingga ditemui banyaknya tanah wakaf yang tidak produktif, terlantar dan bahkan hilang.

b. Peran Yayasan yang mengelola tanah wakaf dari Nadzir perseorangan, kedudukan dan pengaruhnya dipandang lebih tinggi dari pada Nadzir perseorangan.

c. Hasil kekayaan yang diperoleh dari pengelolaan dan pengembangan harta benda wakaf dari pengelola (Yayasan) yang bukan Nadzir seringkali dikuasai oleh Yayasan yang diakuinya sebagai harta kekayaan Yayasan.

d. UU No 41 Tahun 2004 tentang wakaf maupun PP Nomor 42 Tahun 2006 Tentang Peraturan Pelaksanaannya, tidak memberikan wewenang kepada Nadzir dalam melimpahkan tugas pengelolaan harta benda wakaf kepada pihak lain (Yayasan). Sebaliknya, UU Nomor 16 Tahun 2001 sebagaimana diubah 
dengan UU Nomor 28 Tahun 2004

Tentang Yayasan maupun Peraturan

Pelaksanannya yang diatur dalam

PP Nomor 63 Tahun 2008 juga tidak memberikan wewenang Yayasan untuk mengelola harta benda wakaf.

e. Peran Yayasan dalam pemberdayaan dan pengembangan harta benda wakaf membantu tugas Nadzir dipandang lebih berhasil dari pada pengelolaan wakaf yang dilakukan oleh Nadzir perseorangan.

2. Kelemahan-kelemahan tanah wakaf yang dikelola yayasan saat ini

Tanah wakaf dalam perkembangannya masih banyak terdapat masalah baik dari segi pengelolaannya, maupun dari segi pengamanan atau penguasaannya. Tidak sedikit terdapat kasus tanah wakaf yang terjadi di tengah tengah masyarakat yang pada akhirnya terjadi peralihan penguasaan tanah wakaf yang semula merupakan asset umat dan digunakan untuk kepentingan umat menjadi penguasaan hak milik pribadi. Hal yang paling mungkin terjadi adalah penguasaan tanah wakaf oleh nadzir. hal ini dikarenakan pada saat ikrar wakaf hak pengelolaan tanah wakaf diberikan sepenuhnya kepada nadzir, bahkan kebiasaan yang berjalan di masyarakat mengenai hak pengelolaan nadzir belum bisa diganti sebelum nadzir meninggal dunia terlepas nadzir itu lalai atau tidak melakukan tugasnya sesuai dengan ketentuan UndangUndang.

Penguasaan atau dikuasai disini artinya adalah dimiliki secara fisik dalam arti digarap, dihuni, Namun demikian belum tentu dia adalah pemilik atau yang punya tanah itu pengertiannya disini penguasaan dan menguasai dapat dipakai dalam arti fisik, juga dalam arti yuridis. ${ }^{6}$ Juga beraspek perdata dan beraspek publik. Hak penguasaan tanah di sini merujuk pada hak penguasaan yuridis dan fisik yang beraspek keperdataan.

Penguasaan yuridis dilandasi hak yang dilindungi oleh hukum dan umumnya

Boedi Harsono, 1999, Hukum Agraria Indonesia, Sejarah Pembentukan UUPA, Isi, dan Pelaksanaan, Djambatan, Jakarta, hlm.5. memberi kewenangan kepada pemegang hak untuk menguasai secara fisik tanah yang dihaki. Tetapi ada juga penguasaan yuridis yang biarpun memberi kewenangan untuk menguasai tanah yang dihaki secara fisik, pada kenyataannya penguasaan fisiknya dilakukan pihak lain. Misalnya kalau tanah yang dimiliki dikuasai disewakan kepada pihak lain dan penyewa yang menguasainya secara fisik. Atau tanah tersebut dikuasai secara fisik oleh pihak lain tanpa hak. Dalam hal ini pemilik tanah berdasarkan hak penguasaan yuridisnya berhak untuk menuntut diserahkannya kembali tanah yang bersangkutan secara fisik kepadanya. Dalam hukum tanah dikenal juga penguasaan yuridis yang tidak memberi kewenangan untuk menguasai tanah secara fisik. Kreditor pemegang jaminan hak atas tanah mempunyai hak penguasaan yuridis atas tanah yang dijadikan agunan, tetapi penguasaan secara fisik tetap ada pada yang empunya tanah. Berikut merupakan Kelemahan pemberdayaan tanah wakaf yang dikelola yayasan saat ini:

a. Nadzir, Badan Wakaf Indonesia (BWI) maupun Kemenag setempat kurang berperan aktif dalam melaksanakan tugasnya masingmasing sebagaimana yang ditentukan dalam Peraturan Perundangundangan wakaf.

b. Nadzir tidak memiliki wewenang menurut Peraturan Perundangundangan Wakaf untuk melimpahkan sebagian tugas pengelolaan harta benda wakaf kepada pihak lain (perseorangan, organisasi atau badan hukum) untuk tujuan pemberdayaan dan pengembangan harta benda wakaf.

c. Banyaknya tanah wakaf yang terlantar, raib, dan/atau dikuasai oleh pihak lain dengan cara melawan hukum karena lemahnya tingkat profesionalisme Nadzir maupun ketidakjelasan undang-undang tentang status hukum kepemilikan dari hasil pengelolaan dan pengembangan harta benda wakaf. 
d. Peran Yayasan yang bukan Nadzir dalam tugas pengelolaan dan pengembangan harta benda wakaf seringkali melampaui tugas yang diberikan oleh Nadzir dan bahkan Nadzir seringkali disingkirkan dan tidak memiliki peran apapun karena kuatnya peran Yayasan atas pengelolaan tanah wakaf.

e. Yayasan sebagai badan hukum yang diakui cukup berhasil dalam membantu pengelolaan harta benda wakaf dari Nadzir perseorangan tidak memiliki kedudukan yang jelas dimata hukum. Hal ini jelas menghambat upaya penmberdayaan dan pengembangan harta benda wakaf yang dilakukan oleh Yayasan untuk mencapai tujuan wakaf.

\section{PENUTUP}

\section{Kesimpulan}

1. faktor yang menyebabkan Pemberdayaan tanah wakaf yang dikelola yayasan saat ini belum berdasarkan nilai keadilan:

a. Rendahnya tingkat SDM dan profesionalisme Nadzir perseorangan dalam pengelolaan tanah wakaf pada saat ini kurang mendapatkan perhatian maupun pembinaan khusus dari BWI maupun Kemenag. Sehingga ditemui banyaknya tanah wakaf yang tidak produktif, terlantar dan bahkan hilang.

b. Peran Yayasan yang mengelola tanah wakaf dari Nadzir perseorangan, kedudukan dan pengaruhnya dipandang lebih tinggi dari pada Nadzir perseorangan.

c. Hasil kekayaan yang diperoleh dari pengelolaan dan pengembangan harta benda wakaf dari pengelola (Yayasan) yang bukan Nadzir seringkali dikuasai oleh Yayasan yang diakuinya sebagai harta kekayaan Yayasan. d. UU No 41 Tahun 2004 tentang wakaf maupun PP Nomor 42 Tahun 2006 Tentang Peraturan Pelaksanaannya, tidak memberikan wewenang kepada Nadzir dalam melimpahkan tugas pengelolaan harta benda wakaf kepada pihak lain (Yayasan). Sebaliknya, UU Nomor 16 Tahun 2001 sebagaimana diubah dengan UU Nomor 28 Tahun 2004 Tentang Yayasan maupun Peraturan Pelaksanannya yang diatur dalam PP Nomor 63 Tahun 2008 juga tidak memberikan wewenang Yayasan untuk mengelola harta benda wakaf.

e. Peran Yayasan dalam pemberdayaan dan pengembangan harta benda wakaf membantu tugas Nadzir dipandang lebih berhasil dari pada pengelolaan wakaf yang dilakukan oleh Nadzir perseorangan.

2. Kelemahan pemberdayaan tanah wakaf yang dikelola yayasan saat ini:

a. Nadzir, Badan Wakaf Indonesia (BWI) maupun Kemenag setempat kurang berperan aktif dalam melaksanakan tugasnya masing-masing sebagaimana yang ditentukan dalam Peraturan Perundang-undangan wakaf.

b. Nadzir tidak memiliki wewenang menurut Peraturan Perundang-undangan Wakaf untuk melimpahkan sebagian tugas pengelolaan harta benda wakaf kepada pihak lain (perseorangan, organisasi atau badan hukum) untuk tujuan pemberdayaan dan pengembangan harta benda wakaf.

c. Banyaknya tanah wakaf yang terlantar, raib, dan/atau dikuasai oleh pihak lain dengan cara melawan hukum karena lemahnya tingkat profesionalisme Nadzir 
maupun ketidakjelasan undangundang tentang status hukum kepemilikan dari hasil pengelolaan dan pengembangan harta benda wakaf.

d. Peran Yayasan yang bukan Nadzir dalam tugas pengelolaan dan pengembangan harta benda wakaf seringkali melampaui tugas yang diberikan oleh Nadzir dan bahkan Nadzir seringkali disingkirkan dan tidak memiliki peran apapun karena kuatnya peran Yayasan atas pengelolaan tanah wakaf.

e. Yayasan sebagai badan hukum yang diakui cukup berhasil dalam membantu pengelolaan harta benda wakaf dari Nadzir perseorangan tidak memiliki kedudukan yang jelas dimata hukum. Hal ini jelas menghambat upaya penmberdayaan dan pengembangan harta benda wakaf yang dilakukan oleh
Yayasan untuk mencapai tujuan wakaf.

\section{Saran}

1. Dalam pengelolaan harta benda wakaf dibutuhkan partisipasi masyarakat didalamnya, serta peran aktif BWI, Menteri, Wakif dan Nadzir, serta pihak lain yang turut mengelola harta benda wakaf (Yayasan) agar secara bersama-sama mereka berkomitmen untuk memberdayakan dan mengembangkan harta benda wakaf sesuai fungsi, tujuan dan peruntukannya sebagaimana diamanatkan dalam Undang-Undang Nomor 41 Tahun 2004.

2. Yayasan dalam mengelola tanah wakaf membantu Nadzir harus dilakukan pengawasan yang serius baik oleh Nadzir, BWI maupun Kemenag setemt. Yayasan juga diwajibkan membuat laporan kegiatan pengelolaan atas tanah wakaf secara rutin setiap 6 (enam) bulan sekali kepada Nadzir.

\section{DAFTAR PUSTAKA}

\section{- Buku-buku}

Abdul Gani Abdullah, 1992, "Editorial Tentang Perwakafan" dalam Mimbar Hukum Nomor 7 Tahun III, Al-Hikmah dan Ditbinbapera, Jakarta

Asaf A.A Fyzee, 1966, Pokok-Pokok Hukum Islam, terj.Arifin Bey M,A., Cet.2, Tinta Mas, Jakarta;

Boedi Harsono, 1999, Hukum Agraria Indonesia, Sejarah Pembentukan UUPA, Isi, dan Pelaksanaan, Djambatan, Jakarta

Rachmadi Usman, 2009, Hukum Perwakafan Di Indonesia, Sinar Grafika, Jakarta;

Ronny Hannitijo Soemitro, 1990, Metodologi Penelitian Hukum dan Jurumetri, Ghalia Indonesia, Jakarta; 